\title{
Eódzcy poeci dwudziestolecia międzywojennego i ich miasto
}

Od końcowej fazy Młodej Polski aż do wybuchu II wojny światowej Łódź miała sporą grupę poetów. Byli to albo rodowici łodzianie, albo ludzie silnie związani z miastem ${ }^{1}$ : Artur Glisczyński², Aleksander Mogilnic$\mathrm{ki}^{3}$, Antoni Szandlerowski ${ }^{4}$, Zofia Wojnarowska ${ }^{5}$, Jan Nepomucen Miller Julian Tuwim7, Maria Przedborska ${ }^{8}$, Mieczysław Braun', Witold Wandurski $^{10}$, Mieczysław Jastrun ${ }^{11}$, Marian Piechal ${ }^{12}$, Halina Stawarska ${ }^{13}$, Grzegorz \footnotetext{
spole Szkół Salezjańskich im. Ks. Bosko w Łodzi, e-mail: skolster2@gmail.com. kich. Tytuły tych zbiorów podano w kolejnych przypisach.

2 A. Glisczyński, Z mroku i dymu. Poezje, Warszawa 1901.

3 A. Mogilnicki, Z jasnych dni. Poezje, Łódź 1903.

4 A. Szandlerowski, Poezje, Warszawa 1912.

5 Z. Wojnarowska, Poezje, Warszawa 1913.

6 J.N. Miller, Achilles na marach. Dytyramb, Warszawa 1918.

7 J. Tuwim, Czyhanie na Boga, Warszawa 1918.

8 M. Przedborska, Czerwony Krzyż. Poezje z lat wojny, Łódź 1922.

9 M. Braun, Rzemiosta. Poezje, Warszawa 1926.

10 W. Wandurski, Sadze i złoto. Wiersze, Kraków 1926.

11 M. Jastrun, Spotkanie w czasie, Warszawa 1929.

12 M. Piechal, Krzyk z miasta, Warszawa 1929.

13 H. Stawarska, Z dni trosk i ciszy, Warszawa 1929.
}

Absolwent Wydziału Filologicznego Uniwersytetu Łódzkiego, nauczyciel w Ze-

1 Poeci wymienieni zostaną według daty wydania ich debiutanckich tomików poetyc- 
Timofiejew ${ }^{14}$, Kazimierz Sowiński ${ }^{15}$, Zofia Jabłońska ${ }^{16}$, Antoni Kasprowicz ${ }^{17}$, Tadeusz Sarnecki ${ }^{18}$, Konstanty Dobrzyński ${ }^{19}$, Aleksander Kraśniański ${ }^{20}$.

Spośród nich największe uznanie zdobyli tylko trzej: Tuwim, Piechal i Jastrun. Poeci ci, choć spędzili w Łodzi wiele lat swojego życia, niewiele utworów poświęcili miastu. W wymienionej grupie literatów znajdują się wszak tacy, którzy częściej i chętniej sięgali po motywy i tematy łódzkie. Czasem inspiracją była architektura i przestrzeń, a czasami egzystencja mieszkańców, nastroje społeczne lub wyzwania polityczne. Często przybliżali czytelnikom Łódź w wielu swoich wierszach, a czasami dedykowali fabrycznemu grodowi całe tomiki. Dlatego właśnie ich twórczość zostanie w niniejszej pracy poddana analizie. Będą to: Maria Przedborska, Mieczysław Braun, Witold Wandurski, Konstanty Dobrzyński oraz, w drodze wyjątku, Artur Glisczyński - mimo że o interesującym mnie mieście nie pisał wiele w porównaniu z późniejszymi literatami, to należy go uznać za pierwszego "łódzkiego" poetę.

Innym ważnym powodem, dla którego zaprezentowany zostanie dorobek właśnie tych kilkorga wybranych osób, jest chęć udowodnienia, że łódzcy poeci dwudziestolecia międzywojennego często niesłusznie kojarzeni są wyłącznie z dominującym ówcześnie nurtem poezji - z poetyką Skamandra. Praca ma na celu przypomnienie, iż oprócz poetów takich jak Tuwim, który Łódź opuścił, by studiować i rozwijać się literacko, jak Mieczysław Jastrun, dla którego stanowiła ona jedynie pewien etap w życiu, żyli i pracowali tam literaci związani z miastem na stałe, próbujący stworzyć fundamenty życia artystyczno-kulturalnego. Była to grupka kilkanaściorga poetów; wśród nich znajduje się wyżej wymieniona czwórka.

Tematem głównym niniejszego tekstu pozostaje Łódź i jej społeczeństwo. Spuścizna pisarzy takich jak Tuwim, Piechal czy Broniewski została już dawno dosyć skrupulatnie zbadana. O postrzeganiu miasta w dziełach uznanych poetów pisał Tomasz Cieślak w artykule zatytułowanym Kilka uwag o przestrzeni tódzkiej w liryce ${ }^{21}$, do którego będę się jeszcze w niniejszej pracy odwoływał. Dorobek wybranych twórców zostanie zaprezentowany chronologicznie, według dat wydania pierwszych tomów.

Do liryki Łódź wprowadził na początku XX wieku właśnie Artur Glisczyński tomikiem poezji pt. Z mroku i dymu. Ten dziennikarz, poeta i satyryk urodził się w 1869 roku we wsi Machory nieopodal Opoczna. Pochodził

14 G. Timofiejew, Nie ma mnie $w$ domu, Warszawa 1930.

15 K. Sowiński, Gwiazdy na strychu, Warszawa 1930.

16 Z. Jabłońska-Erdmanowa, Kosówka i kaktus, Warszawa 1932.

17 A. Kasprowicz, Stońce za murem, Łódź 1935.

18 T.J. Sarnecki, Poszukiwanie siebie, Warszawa 1935.

19 K. Dobrzyński, Czarna poezja, Poznań 1936.

20 A. Kraśniański, Wiolonczele i księżyc, Łódź 1938.

21 T. Cieślak, Kilka uwag o przedstawieniach przestrzeni łódzkiej w liryce, [w:] Studia i prowincje kultury. Ksiega jubileuszowa ofiarowana profesor Alinie Kowalczykowej, pod red. J. Brzozowskiego, M. Skrzypczyka i M. Stanisza, Warszawa 2012. 
z rodziny szlacheckiej. Do Łodzi przyjechał w wieku dwudziestu lat zaraz po ukończeniu warszawskiej Szkoły Handlowej Leopolda Kronenberga. Pierwszą pracę podjął jako urzędnik Kolei Fabryczno-Łódzkiej. Następnie pracował jako kierownik handlowy fabryki Jana Arkuszewskiego. W tym okresie podjął współpracę z „Dziennikiem Łódzkim”22 oraz, jako korespondent, z gazetami warszawskimi: „Głosem”23 i „Wiekiem”24. W roku 1901 przeprowadził się do Warszawy, aby współpracować z humorystyczno-satyrycznym tygodnikiem politycznym „Kurier Świąteczny ${ }^{\prime 25}$, z „Kolcami" ${ }^{26}$ czy z popularnym „Kurierem Warszawskim” ${ }^{27}$. Zmarł w roku 1910. Jest autorem m.in. kroniki pt. Z roku na rok, która ukazywała się w „Łodzianinie” 28 , oraz współautorem obszernego reportażu Łódź - miasto i ludzie, publikowanego w częściach w „Wieku”29.

Poza Glisczyńskim na przełomie XIX i XX wieku w Łodzi poezję uprawiali także prawnik Aleksander Mogilnicki i duchowny Antoni Szandlerowski. Jednak pierwszy z nich dzielił się z czytelnikami raczej refleksjami na temat społeczeństwa, w którym przyszło mu żyć czy choćby uczuciami do ojczyzny. Drugi, kapłan Kościoła rzymskokatolickiego, nieszczęśliwie zakochany, pisał dramaty i poezje $\mathrm{w}$ duchu młodopolskim. Tematem jego utworów nie jest miasto, lecz np. niespełniona miłość mężczyzny do kobiety; często pojawia się w nich motyw bratnich dusz i współodczuwania ${ }^{30}$.

Glisczyński swojej twórczości nie podporządkował współczesnym tendencjom literackim. Jest to poezja publicystyczna, pisana w nurcie realistycznym, najczęściej dydaktyczna - próżno szukać w niej młodopolskich symboli. Inspirowało go głównie miasto, a konkretnie mieszkańcy Łodzi, przede wszystkim ci z nizin społecznych, robotnicy, dzieci, ludzie kalecy, nierzadko żyjący na granicy nędzy. W wierszu pt. Przy pracy przedstawił włókienniczą fabrykę za pomocą infernalnych opisów, niczym Dante piekło w Boskiej komedii. Podobny zabieg wykorzystał również Reymont w Ziemi obiecanej.

22 „Dziennik Łódzki”, Łódź, od 1884 do chwili obecnej; pierwszy red. - Henryk Elzenberg.

23 "Głos. Tygodnik literacko-społeczno-polityczny", Warszawa, tygodnik wydawany od 1886 do 1905 roku; pierwszy red. - Józef Karol Potocki. Od 1900 r.: „Głos. Tygodnik naukowo-literacki, społeczny i polityczny".

24 "Wiek", Warszawa, od 1873 do 1906 r.; pierwszy red. - Fryderyk Henryk Lewestam.

25 „Kurier Świąteczny”, Warszawa, od 1864 do 1919 r.; pierwszy red. - Arkadiusz Kleczewski.

26 „Kolce. Kartki humorystyczno-satyryczne”, Warszawa, od 1871 do 1914 r.; pierwszy red. - Mieczysław Dzikowski.

27 „Kurier Warszawski”, Warszawa, od 1821 do 1939 r.; pierwszy red. - Bruno Kiciński. Z czasopismem współpracowali najwybitniejsi polscy pisarze, m.in. Bolesław Prus, Kazimierz Przerwa-Tetmajer czy Henryk Sienkiewicz.

28 „Łodzianin. Organ prasowy Polskiej Partii Socjalistycznej, Łódź, od 1919 do 1933 r.; red. - Aleksander Napiórkowski.

29 Zob. T. Gicgier, Opowieści o dawnych poetach Łodzi, Łódź 1995, s. 11-14.

30 Tamże, s. 27-46. 
Dziesiątkiem rzędów na wielkiej sali

Stoją potwory lśniące ze stali,

I pchnięte pasów silnymi sploty

Z swej się bezdusznej budzą martwoty,

Warcząc, zgrzytając w codziennym szale

Piekielnym zgiełkiem wstrząsają salę.

Jak dzikie bestie, ostrymi zęby

Gryząc się wiecznie, trybów szeregi

Błyskawicznymi kręcą się biegi,

Jak pianą pyłów bluzgając kłęby ${ }^{31}$.

Przesadne natężenie czasowników i epitetów sprawia, że wiersz aż kipi od ekspresji. W dalszej części liryku poeta przedstawia naturalistyczny obraz urwanej przez maszynę ręki jednego z robotników:

Obcięto rękaw: kość zdruzgotana

Z urwanej ręki ostrzem sterczała,

Trójkątna, straszna... a poszarpana

Skóra strzępami zwisa długimi [...] $]^{32}$.

Glisczyński jest także autorem satyr. Ich obiektami są przedstawiciele większości warstw łódzkiego społeczeństwa, zarówno inteligencja, jak i fabrykanci oraz przedstawiciele konkretnych zawodów: węglarz, majster, agent, kantorowicz.

W wierszu pt. Majster poeta krytykuje beztroskie życie pracownika jednej z łódzkich fabryk. Tytułowy majster nie boi się przełożonego, nie interesuje go polityka i przyszłość, a jego ulubionym zajęciem jest odwiedzanie knajp po pracy:

Dniem pracuje bez wytchnienia,

„Donner-wetter" klnie.

Wieczór humor i strój zmienia,

I kufelki tnie.

Ma „stammkufel”, jest „stammgastem”,

W knajpce spędza czas,

I potrafi po „piętnastym"

Wołać: „nocheinGlas”!

$[\ldots]$

31 A. Glisczyński, Przy pracy, [w:] H. Karwacka, Artur Glisczyński, pieśniarz fabrycznej Łodzi, Łódź 1975, s. 251.

32 Tamże, s. 253. 
Za łeb trzyma pryncypała,

Własny ceniąc stan.

Kto ten człowiek? - Majster z Wólki -

„So ein Lodzer Mann”33.

W tym miejscu należy zwrócić uwagę na postać lodzermenscha widzianego oczami pierwszego łódzkiego poety. Lodzermensch Glisczyńskiego to majster o dwóch obliczach: za dnia ciężko pracuje, ceni swój talent i fach. Wieczorem spędza beztrosko czas, spożywając niezmierzone ilości alkoholu. Jak widać, ta charakterystyka różni się nieco od definicji, którą można zbudować na podstawie Ziemi obiecanej ${ }^{34}$.

W jednym z wierszy, pochodzącym z cyklu Tragedie miejskie i zatytułowanym Łódź, Glisczyński gloryfikuje miasto. Wyraża zachwyt nad jego wielkością oraz chwali przemysłowy charakter, a bawełniane wyroby wysyłane do innych krajów porównuje do skarbów:

Ponad pola matki-ziemi,

Ponad ciasny szlak,

Wzbił się skrzydły potężnymi

Twórczej pracy znak.

I silnymi wzniósł zamachy

Nowych czasów cud:

Zgrzytem maszyn wrące gmachy,

Wielki, dumny gród!

Jakby skarbów zdrój w legendzie,

On - geniuszu brat -

Barw i kształtów milion przędzie

I posyła $\mathrm{w}$ świat.

\section{$[\ldots]$}

Postęp, twórczość, myśl, co działa, W bratnich sercach siej -

Jak duch dobry - chluba - chwała Matki - ziemi twej! ${ }^{15}$

33 Tenże, Majster, [w:] H. Karwacka, dz. cyt., s. 324.

34 Lodzermensch - po niemiecku i w jidysz: człowiek łódzki - typ łódzkiego fabrykanta, wykształcony pod koniec XIX wieku w warunkach drapieżnego kapitalizmu ówczesnego miasta fabrycznego; kosmopolita, silnie związany z fabryczną Łodzią. W folklorze robotniczym przedstawiany jako silny i nieugięty, pracą własnych rąk stawiający fabrykę, dobry pan. W literaturze - bezwzględny geszefciarz, pozbawiony skrupułów moralnych i tradycji, wyznający swoisty etos interesu, w którym najwyższą wartość stanowi pieniądz, zdobywany najczęściej drogą podstępu i przemocy. Zob. A. Hemer, Twarz lodzermenscha, czyli wizerunek człowieka łódzkiego w "Ziemi obiecanej” Władysława Stanisława Reymonta, "Czytanie Literatury” 2013, nr 2, s. 312.

35 A. Glisczyński, Łódź, [w:] H. Karwacka, dz. cyt., s. 301-302. 
W poezji tego twórcy nie znajdziemy elementów łódzkiej topografii przełomu wieków, obrazów ulic czy architektury. Jest za to wiele opisów fabryk i maszyn fabrycznych, a także pracujących w wielkich zakładach ludzi oraz warunków, w jakich mieszkają najbiedniejsi. Są też obrazy dzieci, jak również typowych mieszkańców Łodzi. Język Glisczyńskiego nie był oryginalny. Bardzo krytycznie wyraził się o poetyce autora Tadeusz Gicgier, wskazując nowatorstwo treści, nie formy:

[...] forma wierszy jest przestarzała nawet jak na tamte czasy, często epigońska, Konopnicka zderza się z Mickiewiczem [...]. Teksty są „przegadane”, ckliwe, neoromantyzm przemieszany z naturalizmem, ale treść? Dzięki tym treściom Glisczyńskiego można z całą odpowiedzialnością za słowo nazwać pierwszym łódzkim poetą urbanistycznym $[\ldots]^{36}$.

Kolejną postacią, której chciałbym poświęcić uwagę, jest Maria Przedborska (1888-1939?) - działaczka społeczna, doktor filozofii, nauczycielka, pielęgniarka, publicystka i poetka. Z ustaleń Tadeusza Gicgiera wynika, iż w naszym mieście żyły i pisały dwie tak samo nazywające się kobiety:

Przy tym nazwisku natknąłem się na prawdziwą zagadkę literacką, której, przyznaję się do tego szczerze, nie udało mi się rozwikłać. Otóż według wszelkiego prawdopodobieństwa żyły i tworzyły w Łodzi pod tym samym imieniem i nazwiskiem - dwie różne poetki, tyle, że w innym czasie.

O Marii Przedborskiej, tej starszej, wiem tylko tyle, że była, jak to się dawniej mawiało, siostrą miłosierdzia. Świadczą o tym jej dwie publikacje: drukowany w "Robotniku” w roku 1919 w odcinkach Pamiętnik siostry Czerwonego Krzyża oraz wydane w Łodzi nakładem Księgarni Polskiej w roku 1922 poezje z lat wojny pod tytułem Czerwony Krzyż. I na tym moja wiedza o tej poetce się kończy.

Druga Maria Przedborska urodziła się w Łodzi w roku 1915. Uczęszczała do łódzkiego Gimnazjum im. E. Orzeszkowej, które ukończyła w roku $1933^{37}$.

Okazuje się jednak, że Gicgier nie błysnął dziennikarskim i detektywistycznym zmysłem, starając się odtworzyć biografię łódzkiej poetki. Wystarczyło przyjrzeć się jedynie życiu tej pierwszej Marii.

Andrzej Kempa tak rozpoczął swój artykuł poświęcony Marii Przedborskiej w „Kronice Miasta Łodzi”:

Sprawcą całego zamieszania był Tadeusz Gicgier, który w swojej książce Opowieści o dawnych poetach Łodzi wydobył z zapomnienia postać łódzkiej

36 T. Gicgier, dz. cyt., s. 15-16.

37 Tamże, s. 133. 
poetki Marii Przedborskiej. Całkiem niesłusznie jednak dodał jej do towarzystwa młodszą kobietę o tym samym imieniu i nazwisku, która miała się jakoby urodzić w 1915 r., do 1933 r. uczęszczała do łódzkiego Gimnazjum Żeńskiego im. Elizy Orzeszkowej, pisywała wiersze, drukowane w łódzkiej prasie, w 1937 r. wyemigrowała z Łodzi i ślad po niej zaginął. Pisarz dość bezkrytycznie wykorzystał informacje zawarte w nocie biograficznej zamieszczonej w antologii poezji o Łodzi, opracowanej przez Ziemowita Skibińskiego i Barbarę Stelmaszczyk-Świontek ${ }^{38}$.

Najważniejsze fakty z jej życia znajdujemy m.in. w czwartym tomie słownika biograficznego Żydzi dawnej Łodzi Andrzeja Kempy i Marka Szukalaka ${ }^{39}$. Prawdopodobnie autorka Wśród kominów Łodzi była pochodzenia żydowskiego ${ }^{40}$. Według Henryka Makowera jesienią 1939 roku prowadziła w warszawskim getcie kursy maturalne dla uczniów szkół średnich. Data i miejsce jej śmierci są nieznane ${ }^{41}$.

Poetycka przynależność Marii Przedborskiej do grup literackich dwudziestolecia międzywojennego nie jest oczywista. Co prawda wersyfikacja w jej tekstach wskazuje na styl skamandrytów (klasyczna budowa wiersza), ale tematycznych powiązań z poezją tej grupy nie znajdziemy.

Z jej życiorysu nie dowiemy się, czy utrzymywała kontakty z innymi poetami międzywojennej Polski, czy też brała udział w spotkaniach literackich, tak jak robili to np. skamandryci w kawiarniach. Trudno też doszukać się w twórczości Przedborskiej inspiracji innymi poetami. Jej praca zawodowa również nie była związana z literaturą.

38 A. Kempa, Odkryta tajemnica. Kim była Maria Przedborska, „Kronika Miasta Łodzi” 2008, nr 3, s. 271.

39 A. Kempa, M. Szukalak, Żydzi dawnej Łodzi. Słownik biograficzny Żydów łódzkich i z Łodzia związanych, t. 4, Łódź 2004, s. 272.

40 Felicja Maria Przedborska urodziła się 30 października 1888 roku. Była córką lekarza. Po ukończeniu żeńskiego gimnazjum w Białymstoku podjęła studia na Uniwersytecie Jagiellońskim, ale po dwóch semestrach przeniosła się na studia do Zurychu. Tam też 3 maja 1911 roku otrzymała promocję na stopień doktora filozofii w zakresie pedagogiki. Wkrótce potem wróciła do kraju. Nauczała w żeńskim gimnazjum Fanny Poznerowej w Warszawie. Pierwsze utwory publikowała w warszawskim miesięczniku „Sfinks” oraz tygodniku „Widnokrąg". Podczas I wojny światowej pracowała jako pielęgniarka w wojskowych szpitalach. Okres ten zaowocował opowiadaniem Z pamiętnika siostry Czerwonego Krzyża i wierszami zebranymi w tomiku Czerwony Krzyż. Od 1925 roku była nauczycielką historii i propedeutyki filozofii w Gimnazjum Żeńskim Eugenii Jaszuńskiej-Zeligmanowej w Łodzi. Po kilku latach nauczania została zatrudniona w Inspekcji Pracy jako podinspektor pracy do spraw kobiet i młodocianych. Owocami jej badań i kontroli były artykuły w "Głosie Porannym”: Samowola majstrów wobec robotnic (1932, nr 106), Robotnica tódzka w świetle faktów i wspomnień (1938, nr 146) oraz esej Kobieta w tódzkim przemyśle, [w:] Księga pamiątkowa Syndykatu Dziennikarzy Łódzkich, Łódź 1939. Także na łamach „Głosu Porannego" w latach 1932-1936 ukazał się jej cykl wierszy Wśród kominów Łodzi, inspirowany egzystencją kobiet zatrudnionych w łódzkim przemyśle (zob. A. Kempa, Odkryta tajemnica..., s. 271).

41 A. Kempa, M. Szukalak, Żydzi dawnej Łodzi, s. 154-155. Kempa w przypisie do artykułu poświęconego Przedborskiej w „Kronice Miasta Łodzi” dodaje notatkę: „Makower uznał, że Przedborska była polonistką. Być może organizatorzy kursów powierzyli jej, wobec braku innego nauczyciela, prowadzenie wykładów z języka i literatury polskiej". Tenże, Odkryta tajemnica..., s. 272. 
Maria Przedborska posiada talent - umie się zdobyć na siłę wyrazu - ma dar obrazowania. Niejeden też z jej wierszy budzi silny oddźwięk.

Razi tylko nieraz sztuczna afektacja i jednostronność tematów. Brak w poezji Przedborskiej jakichkolwiek świateł - autorka jakby z góry obrała sobie za cel gromadzenie samych cieni i dobieranie ich do ustalonego poprzednio tematu - zachodzi też obawa, by autorka nie popadła w pewne zmanierowanie... Należałoby nie ograniczać się tylko do zewnętrznych objawów życia, ale wniknąć w głąb, sięgnąć do psychiki i świata myśli społecznej Łodzi, a wówczas poezja, zyskawszy silną podstawę myślową, stanie się poezją wartości nieprzemijającej ${ }^{42}$.

Stolarzewicz ma rację - Przedborską interesuje tylko to, co zewnętrzne: obraz ludzkiej egzystencji. W jej wierszach niewiele jest środków poetyckich, tj. metafor, porównań, apostrof, anafor czy animizacji. Cała twórczość oparta jest na budowaniu drastycznych i pesymistycznych obrazów:

Lat dziewiętnaście. Prządka od Geyera

Proletariacka choroba: suchoty.

Szpitalny pokój. Dzień majowy, złoty.

Krótko się żyje, lecz długo umiera!...

Prządka... Gorąco w sali płuca zżera...

wilgoć pierś dławi... krew huczy w tętnicach.

Obsługi żąda wciąż samoprząśnica:

Pilną być musi prządka u Geyera!43

W twórczości Marii Przedborskiej nie znajdziemy elementów sielankowości czy melancholii (w przeciwieństwie do twórczości Wandurskiego i Dobrzyńskiego). Niewiele jest tu także obrazów architektury prezentujących „zewnętrzną" przestrzeń miasta, za to dużo naturalizmu. Najczęściej scenerią wierszy poetki są wnętrza fabryk lub nędznych mieszkań. Autorka postawiła sobie za zadanie obnażenie realiów egzystencji łódzkich robotników, co wiązało się także z jej działalnością w Inspekcji Pracy. Bohaterowie utworów Przedborskiej chorują, głodują, pracują, wegetują w obskurnych izbach i często umierają. Wydaje się, że jej poezja miała na celu rozbudzanie w czytelnikach „Głosu Porannego" wrażliwości na ludzką krzywdę i niedolę. Większość wierszy stanowią pesymistyczne scenki rodzajowe. W tym brudnym i cuchnącym świecie nie ma najmniejszej nadziei na zmianę warunków życia. Nie ma żadnych pozytywnych elementów.

W utworze pt. Niedziela letnia poetka prezentuje następującą scenę: małżeństwo robotników z trójką dzieci wybrało się w gorące letnie popołudnie

42 L. Stolarzewicz, Literatura Łodzi w ciągu jej istnienia. Szkic literacki i antologia, Łódź 1935, s. 87.

43 M. Przedborska, Suchoty, "Ilustrowana Rewia Tygodniowa” 1934, nr 22, s. 4. 
na spacer do parku. Jedno z dzieci coś zbroiło i rodzice będą musieli pokryć koszty wyrządzonej szkody. Mężczyznę ponoszą nerwy, postanawia się upić. Kobieta, świadoma trudnej sytuacji finansowej rodziny, popada w rozpacz. Ale co innego w tym tekście zwraca uwagę czytelnika. Mianowicie opis łódzkich parków. W mieście pełnym ludzkich nieszczęść nawet przyroda zdaje się chorować i cierpieć:

Miejskie parki: drzew niewiele, suchotnicze krzewy,

nędzny trawnik i ławki - nie ma niezajętej!

Chodź i szukaj - tu i tam: obie odparz pięty,

Jeśli chcesz wygnać $\mathrm{z}$ siebie fabryczne wyziewy ${ }^{14}$

Łatwo można dostrzec kontrast w postrzeganiu podobnej przestrzeni, jaką jest park, w twórczości dwojga poetów - Dobrzyńskiego i Przedborskiej. U Dobrzyńskiego: barwne kwiaty, zieleń, złote słońce - u poetki: uboga roślinność, „umierające” krzewy, brak wolnych ławek, brak jakichkolwiek barw. W jednym z numerów "Głosu Porannego", w którym ukazało się kilka wierszy Przedborskiej z cyklu Wśród kominów Łodzi, poetka dodała dedykację:

\section{ROBOTNICY ŁÓDZKIEJ}

- jej pracy, zmaganiom i męce,

jej modlitwom, zawodom i przekleństwom

jej życiu, konaniu i śmierci

jej bohaterstwu kobiecemu ${ }^{45}$.

Los łódzkich robotnic i ich dzieci był najważniejszym tematem poezji Przedborskiej. Eksponując biologizm i fizjologię, poetka akcentowała wysiłek i nierówne traktowanie płci. Tego problemu dotyczy wiersz pt. 8 godzin:

Stoi przy swym warsztacie długich osiem godzin, gdy podczas menstruacji kurcze szarpią ciało, ręce wznosi i czuje, jak krew z niej uchodzi stoi - spocząć nie wolno choć na chwilę małą

Stoi przy swym warsztacie długich osiem godzin, gdy płód, w niej dojrzewając, rozdyma ją całą:

lekarz nie da zwolnienia (,żadnej to nie szkodzi!”), stoi - spocząć nie wolno choć na chwilę małą!

Stoi przy swym warsztacie długich osiem godzin, gdy nogi z żylakami są masą nabrzmiałą,

44 M. Przedborska, Niedziela letnia, „Ilustrowana Rewia Tygodniowa” 1935, nr 33, s. 2.

45 Taż, Robotnicy łódzkiej, "Głos Poranny” 1934, nr 354, dod. „Specjalny dodatek świąteczny", s. 2. 
której bólu podwyżka nawet nie łagodzi,

Stoi - spocząć nie wolno choć na chwilę małą!t6

Poetą łódzkim, którego twórczości chciałbym poświęcić uwagę, jest także Mieczysław Braun (właściwie Aleksander Mieczysław Bronsztejn, 1902-1941?) - weteran wojny polsko-bolszewickiej, prawnik i publicysta ${ }^{47}$.

Jego twórczość należała do tzw. „poezji pracy”. Czytelniczym powodzeniem cieszyły się szczególnie dwa pierwsze opublikowane przez niego tomy: Rzemiosta i Przemysty ${ }^{48}$.

Jerzy Kwiatkowski w podręczniku dotyczącym literatury okresu międzywojnia wspomina pięciu poetów związanych z Łodzią. Są to Julian Tuwim, Mieczysław Jastrun, Marian Piechal oraz Mieczysław Braun i Witold Wandurski, a więc głównie ci, którzy związani byli ze środowiskiem warszawskim. Nie poświęca ani słowa twórczości Konstantego Dobrzyńskiego czy Marii Przedborskiej. Świadczy to o drugorzędności ich poezji, języka i warsztatu. O Braunie czytamy w podręczniku Kwiatkowskiego:

\begin{abstract}
Pojawił się też w ówczesnej poezji - zwłaszcza w twórczości Iwaszkiewicza, Stefana Napierskiego, Mieczysława Brauna i właśnie Ludwika Hieronima Morstina - zwrot ku stylizacji. Polegał on głównie na podejmowaniu pewnych gatunków klasycznych, takich jak oda, elegia, list poetycki, w mniejszym stopniu- na delikatnej archaizacji wersyfikacyjno-składniowej. W każdym razie klasycystyczna stylizacja nie zdominowała klasycystycznych ideałów prostoty, jasności, wyrazistości. Toteż jest to okres, w którym poezja skamandrycka staje się najbardziej klarowna, zrównoważona artystycznie, "przezroczysta"49.
\end{abstract}

Łódzki poeta zaliczony został do nurtu skamandryckiego, i słusznie. Jego związki ze Skamandrem sięgają jeszcze lat młodzieńczych. W okresie gimnazjalnym nawiązał znajomość z Julianem Tuwimem. W roku 1919 ukazał się jedyny numer „Tańczącego Ognia”, którego współtwórcami byli siedemnastoletni wówczas Braun oraz inny młody łódzki poeta - Aleksander Kraśniański. Braun zamieścił w piśmie trzy wiersze oraz jedną notę krytyczną. Warto dodać, iż w „Tańczącym Ogniu” dwa utwory opublikował także Antoni Słonimski.

Po rozpoczęciu studiów na warszawskim wydziale prawnym zawarł nowe znajomości z literatami warszawskimi, zarówno skamandrytami, jak i futurystami. Przyjaźnił się z Władysławem Broniewskim. Na początku lat

46 Taż, 8 godzin, „Głos Poranny” 1934, nr 354, dod. „Specjalny dodatek świąteczny”, s. 2.

47 B. Tyszkiewicz, Braun Mieczystaw, [w:] Wspótcześni polscy pisarze i badacze literatury. Stownik biobibliograficzny, pod. red. J. Czachowskiej i A. Szałagan, t. 1, A-B, Warszawa 1994, s. 272-273.

48 J. Maciejewski, Wstęp, [do:] M. Braun, Wybór poezji, Warszawa 1979, s. 9-10.

49 J. Kwiatkowski, Dwudziestolecie międzywojenne, Warszawa 2012, s. 115. 
dwudziestych publikował wiersze w czasopismach takich jak: „Skamander" ${ }^{\prime 50}$, „Nowa Sztuka" ${ }^{51}$, „Wiadomości Literackie" ${ }^{\prime 52}$. Częściej niż w Warszawie Braun przebywał w Łodzi - w stolicy nie wynajmował nawet stancji, często nocował u znajomych - gdzie zaczęło się kształtować środowisko literackie. Od czasu do czasu w rodzinnym mieście brał z Tuwimem udział w spotkaniach autorskich ${ }^{53}$.

Prócz sonetów zdarzało mu się pisać elegie czy ballady. Podobnie jak Jana Lechonia inspirowała go poezja wieszczów romantycznych. W jego zbiorach odnajdziemy wiersze poświęcone Mickiewiczowi czy Słowackiemu np. Duma o Stowackim, O Mickiewiczu (ale także Wspomnienie o Żeromskim) a ponadto utwory wprost nawiązujące do ich twórczości. W lirykach Brauna tradycja literacka romantyków miesza się z fascynacją zdobyczami techniki początku dwudziestego wieku:

Śród zielonego suchej trawy oceanu,

Jak łódź samotna, tonąc na dalekim Krymie,

Mijając koralowe ostrowy burzanu,

Słuchaj fali: ktoś woła na Litwie twe imię!

Już iskra elektryczna niewidzialną drogą

Glob obiegła, w powietrze wsiąkła jak w bibułę,

Już mogą ją pochwycić i słyszeć ją mogą -

Aparaty najczulsze i serca nieczule ${ }^{54}$.

U Kwiatkowskiego czytamy:

Szczególnie ciekawa była tu poezja Brauna, zarówno ze względu na nieczęstą wówczas tematykę pracy: tytuły jego pierwszych dwu tomików brzmiały Rzemiosła i Przemysty, jak i z racji jego drogi ku klasycyzmowi: wiodła ona przez próby futurystyczne i awangardowe, jak wreszcie dzięki wyborowi tradycji: bodajże jako pierwszy Braun sięgnął do klasycyzmu epoki stanisławowskiej i początków XIX wieku ${ }^{55}$.

Co prawda ma Braun w swoim dorobku sporą liczbę „zgrabnych” wierszy, ale do geniuszu Tuwima mu daleko. Widać to szczególnie w lirykach, które nie znalazły się w zbiorach wydanych po wojnie. Tak jest w przypadku

50 „Skamander", Warszawa, od 1920 do 1928 oraz od 1935 do 1939. Miesięcznik poetycki. Pierwszy red. - Władysław Zawistowski.

51 „Nowa Sztuka”, Warszawa, od 1921 do 1922; red. Anatol Stern. Ukazały się jedynie dwa numery tego czasopisma awangardy poetyckiej.

52 „Wiadomości Literackie” - tygodnik społeczno-kulturalny o orientacji liberalnej wydawany w latach 1924-1939 w Warszawie; red. Mieczysław Grydzewski.

53 J. Maciejewski, dz. cyt., s. 9-32.

54 M. Braun, Radio, [w:] tegoż, Wybór poezji, s. 135.

55 J. Kwiatkowski, dz. cyt., s. 122. 
Wiersza o Łodzi. Poeta przesadza z ekspresją w obrazowaniu, a samo miasto jest ukazane w sposób tandetnie naturalistyczny, banalnością rażą również rymy:

Nazywa się po prostu i krótko: Łódź,

$[\ldots]$

Stopiony asfalt syczy i wre,

ryją galery spienione smugi,

i miażdżą dziobem: łamią krę

olbrzymie ptaki-pługi.

Maszyny gryzą kamienny chleb,

maszyny - maszyny - maszyny pędzą.

O bruk uderza potworny łeb,

ścięty okrutną nędzą!

O, czarne miasto! Czarny śnie!

Krwotoku płucny! Klątwo gniewna!

Spiętrzone mury! Szare dnie!

Piosenko śpiewna, rzewna!....

Rzemiosła (1926) oraz Przemysty (1928) wróżyły Braunowi pomyślną przyszłość literacką. Stało się jednak inaczej. Poeta wybrał karierę prawniczą, poezją zajmował się już tylko sporadycznie w wolnych chwilach. Kolejne tomy Liść dębowy (1929) i Żywe stronice (1936) nie cieszyły się tak dużym zainteresowaniem jak wcześniejsze.

Łódź Mieczysława Brauna jest świętym miastem pracy. Toteż poetę interesuje to, co dzieje się wewnątrz warsztatów, fabryk i zakładów świadczących pomniejsze usługi, jak w wierszu Łódź fabryczna, w którym wymienione zostają elementy charakterystyczne dla przemysłowego krajobrazu:

Warkocze dymów kłębami nad Łodzią czarną płyną,

Robocza kurzawa ulic w niebo uderza ofiarnie,

Czeszą je w górze szczerbate grzebienie wzniosłych kominów,

Wszystkie warsztaty turkocą, palą się wszystkie latarnie ${ }^{57}$.

Na twórczość Mieczysława Brauna ogromny wpływ wywarła rozprzestrzeniająca się $\mathrm{w}$ dwudziestoleciu międzywojennym ideologia socjalistyczna. Jako człowiek o poglądach lewicowych za główny temat poezji obrał sobie opiewanie pracy, pisał o niej w sposób patetyczny. Ten etos pracy związany z odbudową kraju był charakterystyczny raczej dla twórców awangardy (szczególnie dla Juliana Przybosia) niż dla skamandrytów. Łódzki poeta poświęcił owej idei niemal całe dwa pierwsze tomy:

56 M. Braun, Wiersz o Łodzi, [w:] Łódź od A do Z. Informator uniwersalny, Łódź 1958, s. 174-175.

57 Tenże, Łódź fabryczna, [w:] tegoż, Wybór poezji, s. 148. 
Przemysty oraz Rzemiosła. Braun zakłady stawia na równi z kościołami, pracę na równi z nabożeństwami. Fascynują go odgłosy i ruch maszyn w łódzkich przedsiębiorstwach.

W kościołach czerwonych fabryk krążą pośpiesznie i gwarnie

Pasy szumiące i dźwignie i dyszą płuca olbrzymów,

Spieszą się tkalnie, przędzalnie, wrą kolorowe farbiarnie

Pieśnią twórczego rozpędu, tryskają strofami hymnów!

Kwitnie w motorach i syczy błękitny sen - acetylen,

W południe dzwoni hejnałem tysiąc blaszanych syren,

Na czarnych walcach owite rosną radosną potęgą:

Sukno, alpaga i korty, grube włochate marengo, -

W halach fabrycznych włókniarze stęsknione unoszą twarze,

Przy nabożeństwie warsztatów turkocą maszyn ołtarze ${ }^{58}$.

Nastroju zadumy nie uniknął Braun podobnie jak Wandurski i Dobrzyński. Jeden z takich melancholijnych liryków znajdziemy w tomie Sonety z 1937 roku. Opatrzył go poeta numerem II.

Dwa miasta w jednym. To, oddane wrzawie,

Gdzie tłum się tłoczy kamienistą drogą

Śród noży spojrzeń skrzyżowanych wrogo,

Tu swar wybucha przy powszechnej sprawie.

Tamto - odludne, nie ma w nim nikogo,

Tam cień przemyka po zwiędłej murawie.

Samotny błądzę, oglądam na jawie

niebo samotnych, uśmiechnięte błogo ${ }^{59}$.

W liryku nie pada nazwa miasta, nie ma też nazw ulic ani charakterystycznych elementów architektury, możemy się jedynie domyślać, że chodzi właśnie o Łódź, w której Braun spędził większość swojego życia i która była mu najbliższa. Być może jednak poeta miał na myśli miasto w ogóle, każde w tym kraju. W utworze podmiot liryczny wyraża swoją alienację spośród całej rzeszy mijanych ludzi, z którymi się nie identyfikuje. Przechodnie są nastawieni do siebie wrogo, przez co potęguje się uczucie grozy i liryk nosi znamiona katastrofizmu. Miasto tworzą jakby dwie różne aglomeracje, które wydają się surrealne, a jednocześnie prawdziwe. Nawet podmiot liryczny ma poczucie sobowtórowości:

58 Tamże.

59 M. Braun, II, [w:] tegoż, Wybór poezji, s. 204. 
W jednym i drugim mieszkam jednocześnie,

Dokoła domy, rysowane we śnie,

Słońce na krańcach gaśnie jak pochodnia.

Tu na granicy obu miast, jak w chmurze,

Nagle spotykam twarzą w twarz przy murze

Siebie, pełnego zadumy przechodnia ${ }^{60}$

Miasto stanowiło także inspirację twórczą dla Witolda Wandurskiego (1891-1934), publicysty, działacza społecznego, dramaturga, dyrektora teatru w Charkowie i kierownika teatru w Kijowie, a pod względem ideowym zwolennika socjalizmu ${ }^{61}$. Twórca w Łodzi na stałe osiadł w 1921 lub 1922 roku. Jest autorem takich sztuk jak np. Raban, Giełda światowa oraz burleski jarmarcznej Gra o Herodzie ${ }^{62}$.

Do jakiej grupy poetyckiej zaliczyć Witolda Wandurskiego? Ta kwestia nie jest oczywista. W Dwudziestoleciu międzywojennym Kwiatkowskiego niewiele znajdziemy informacji o jego twórczości:

Istnieje pewne podobieństwo łączące zwrot ku klasycyzmowi ze zwrotem ku poezji społecznej. Klasycyzm to zdominowanie wyzwolonej sztuki przez rygor i tradycję. Poezja społeczna to zdominowanie wyzwolonej jednostki - przez poczucie obowiązku wobec zbiorowości. [...]

Zasadniczą zmianę wprowadzają pod tym względem - ściślej czy luźniej związani z ruchem robotniczym, niekiedy z partią komunistyczną - poeci lewicy. Z jednej strony - futuryści czy już raczej eksfuturyści: przede wszystkim Jasieński i w pewnej mierze Stern, a także dwaj poeci innej formacji mniejszego lotu, najbardziej zaangażowani politycznie, Witold Wandurski i Stanisław Ryszard Stande. Z drugiej strony - Broniewski ${ }^{63}$.

Tyle o Wandurskim jako poecie. Opinia dość krytyczna. Ale czy słuszna? I jaka właściwie to jest ta „inna formacja”? Wiadomo, że nie futuryzm. Skamandrycka? Awangardowa?

Poeta posługiwał się przeróżnymi systemami wersyfikacyjnymi, począwszy od wierszy wolnych (Gołębiarz), poprzez wiersze nieregularne (Od pótnocy do świtu), aż po wiersze o układzie klasycznym (Miejskie, Wleśniczówce, Stolarka). Na uwagę zasługuje też słownictwo w twórczości Wandurskiego:

60 Tamże, s. 204.

61 Por. M. Kotowska-Kachal, Wandurski Witold, [w:] Wspótcześni polscy pisarze i badacze literatury, t. 9, W-Z, Warszawa 2004, s. 26-29.

62 T. Gicgier, dz. cyt., s. 89-96.

63 J. Kwiatkowski, dz. cyt., s. 126-127. 
kamgarn ${ }^{64}$ czy brandmaury ${ }^{65}$ - wyrazy pochodzenia niemieckiego, dziś archaizmy - dawniej słowa wsiąknięte w język łódzkiej społeczności początku $\mathrm{XX}$ wieku, oddające jej wielokulturowy charakter. Jedyny tom poetycki Wandurskiego ukazał się w 1926 roku. We wstępie do niego czytamy: „Wiersze i litografie tego tomu powstały - niezależnie od siebie - na bruku łódzkim w okresie 1922-1924"66. Tak więc za ucznia Tadeusza Peipera, który swój debiutancki zbiór $A$ wydał w 1924 roku, Wandurski uznany być nie może, ale gdyby rozpatrywać wiersze łodzianina pod kątem ideologicznym, to zauważymy, że zdecydowanie więcej łączy go z Awangardą Krakowską niż ze środowiskiem skamandrytów.

U Witolda Wandurskiego, podobnie jak i u twórców Awangardy Krakowskiej, można dostrzec np. fascynację nową, industrialną cywilizacją, propagowanie ideału pracy niezbędnej do odbudowy niepodległego państwa polskiego czy poetykę zaszyfrowanego zdania wymagającego wielokrotnej lektury, koniecznej do właściwej interpretacji utworu poetyckiego. W wielu wierszach Wandurskiego pojawiają się obrazy miejskiej architektury, nazwy ulic czy różne atrakcje związane z egzystencją w aglomeracji, ale nie jest mu obca również tematyka ciężkiej, społecznej pracy:
Jeśli wolno mi jeszcze marzyć
Niech marzenie doda mi sił:
Chcę nauczyć się kunsztu stolarzy
Muzyki hebla i pił.
$[\ldots]$
Białą skórę na dłoniach wydrę
Byle tylko stolarzyć wciąż
Byle mordą stalową świdra
Wgryzać się w drzewny miąższ ${ }^{67}$.

Dorobek poetycki Wandurskiego jest niezwykle skromny - obejmuje zaledwie kilkanaście wierszy i jeden poemat. Być może dlatego właśnie Kwiatkowski niepochlebnie wypowiedział się na jego temat, ale na tle innych łódzkich poetów twórczość Wandurskiego wydaje się niebanalna, kunsztowna, niezwykle obrazowa i wpływająca na emocje.

To właśnie w jego wierszach szczególnie interesująco została naszkicowana przestrzeń miejska. W Gołębiarzu architekturę łódzką zaprezentowano

64 Kamgarn (niem.) - a) wełniana przędza dobrego gatunku, o długiej, równej, bardzo cienkiej nici, produkowana z surowca przerobionego na czesarkach, b) gładka tkanina z wełny czesankowej. Hasło [w:] Słownik wyrazów obcych PWN, pod. red. Hipolita Szkiłądzia, Warszawa 1971, s. 334.

65 Brandmauer (niem.) - mur ogniowy, ściana, zwykle z niepalnego materiału, oddzielająca dwie sąsiednie budowle lub części tej samej budowli, chroniąca przed szerzeniem się pożaru. Tamże, s. 93.

66 W. Wandurski, Sadze i złoto, Łódź 1926, s. 6.

67 Tenże, Stolarka, [w:] tegoż, dz. cyt., s. 40. 
jako zbiór elementów geometrycznych; zauważamy w niej także cechy krajobrazu górskiego, co wskazuje na ogrom i grozę budynków przemysłowego miasta, na majestat podobny do tego, jaki wzbudzają góry:

Świt.

Kamgarn nieba wysycha po deszczu na słupach kominów

Kamienne miasto, opiłe pracą, śni sen,

Kuby domów.

Czerwone bloki masywów ${ }^{68}$.

Jednocześnie już w drugim wersie zasygnalizowany został włókienniczy i fabryczny charakter miasta, między innymi poprzez metaforę kamgarnu nieba. Pojawiają się charakterystyczne dla obrazowania Łodzi elementy takie jak kominy fabryk czy kolor ścian: czerwony - ceglany.

W dalszej części utworu podmiot liryczny przedstawia czytelnikowi jednego z mieszkańców miasta - tytułowego bohatera wiersza:

Wchodzi ten, który czuwa nad miastem:

siwiejący gołębiarz.

Otwiera klapę drucianą,

sypie groch,

gwiżdże ${ }^{69}$.

Ów siwiejący gołębiarz nie jest postacią jednoznaczną. Sformułowanie „który czuwa nad miastem" nadaje mu charakter mityczny bądź biblijny, mimo iż jego praca, tj. sypanie grochu czy wypuszczanie gołębi z klatki, nie jest niczym niezwykłym. Niezwykły za to staje się lot gołębi, sprowadzony niemal do aktu religijnego:

Stalowo-sine pocztowce.

I ta hołota - metysy upośledzone - pstre siekry.

Siwiejący gołębiarz, gwiżdżąc, spogląda ku górze

I macha sztandarem.

Misterium!

[...]

Jedyna radosna krzywa! $!^{70}$

\footnotetext{
68 Tenże, Gołębiarz, [w:] tegoż, dz. cyt., s. 5.

69 Tamże, s. 6.

70 Tamże.
} 
Podmiot liryczny wyraża zachwyt nad chaotycznym, wolnym lotem ptaków, stanowiącym kontrast dla geometrycznej i uporządkowanej architektury miasta. Jednocześnie „obrzęd" ma znamiona zjawiska tajemniczego, magicznego i fascynującego, a sam gołębiarz kreowany jest na biblijnego proroka lub kapłana, próbującego odczytać przyszłość z lotu ptaków, lub też Noego, który na swej arce wypatruje od gołębi znaku - symbolu odrodzonego po katastrofie nowego świata.

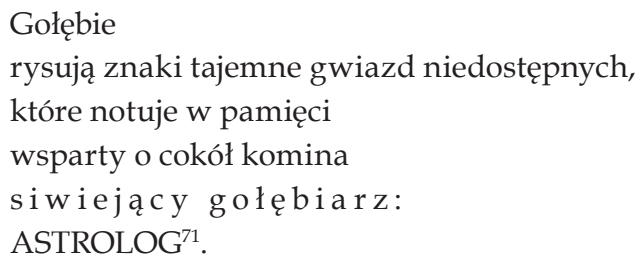

Niezwykle romantyczno-baśniową wizję miasta rysuje poeta w wierszu Kapitan Nemo. To przestrzeń zatopiona w „oceanie nocy”. Autor odwołuje się do mitologii, nazywając fabryczną „ziemię obiecaną" „Atlantydą zatopionych miast". Zatopionych aglomeracji można wskazać wiele, ale Łódź jest tym miastem nieodkrytym i niezbadanym nocą. Nie jest ono tym samym, które tętni życiem za dnia. Poeta postrzega je niby egzotyczną, koralową rafę pełną życia. Po raz kolejny wyróżnia takie składniki architektury jak kominy czy kamienice, ale też maszyny przemysłowe i środki lokomocji - dla niego to żywe istnienia:

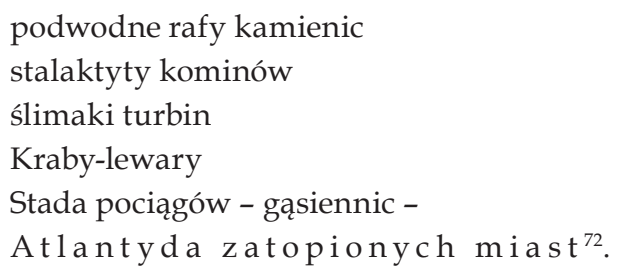

Jesień jest porą dżdżystą i deszczową - miasto tonie w wodzie. Podmiot liryczny utworu przedstawia siebie jako nurka, osobę obcą dla tego podwodnego świata. Niechętnie przemierza ulice. Chciałby płynąć wyżej ku księżycowi.

W jesiennym palcie, jak w zbroi skafandra chodzę po miejskim dnie.

Gumowa salamandra.

Nurek.

[...]

Ołów moich podeszew w trotuarach tonie.

Zapadam w muł.

\footnotetext{
71 Tamże, s. 7.

72 Tenże, Kapitan Nemo, [w:] tegoż, dz. cyt., s. 21.
} 
Kapitanie!

Ciągnąć do góry! $!^{73}$

Ten podwodny świat jest niebezpieczny i nieprzyjazny dla człowieka:

między rafami kamienic

biegają spłoszone gady - automobile -

i sączą tubkami źrenic

jad - acetylen.

W zielonym blasku

migają rozchybotane plamy

- ludzie czy ryby? -

i wystraszone mą gumową maską

znikają w niebieskim szlamie ${ }^{74}$.

W poemacie Od pótnocy do świtu Łódź ukazana została w sposób niemal młodopolski - pobrzmiewa w nim bowiem głos melancholii i zadumy. Po raz kolejny podmiot liryczny porusza się po mieście nocą. Nastrojowość utworu oddana jest za pomocą wrażeń zmysłowych: barwy, smaku, dźwięku. Uczucie melancholii potęguje sygnalizowana jako pora roku pełnia jesieni, jak i również częściowa rytmizacja wiersza.

Iść - iść - iść ulicami

Zadumanemi nocami mądrej jesieni.

Iść ulicami: Karola - Pańską - Radwańską -

hen - na Karolew ${ }^{75}$.

Bohater przemierza konkretne ulice w konkretnym kierunku, lecz punkt dojścia pozostaje nieznany. Wydaje się, że celem samym w sobie jest ruch podążanie przed siebie, sprawiające wrażenie procesu automatycznego, niemal lunatycznego. Fabryczne miasto wypełnione jest dymem i chłodem, ale jednocześnie w tej mroźnej i zadymionej przestrzeni dominują witalność i pragnienie życia werbalizowane przez podmiot liryku - mieszkańca Łodzi:

Zadymionemi płucami

pić wino z lodem,

pić to powietrze jesieni

pachnące wiatrem i szronem

i ciałem młodem

mej żony ${ }^{76}$.

73 Tamże, s. 22.

74 Tamże, s. 22-23.

75 Tenże, Od pótnocy do świtu, [w:] tegoż, dz. cyt., s. 13.

76 Tamże. 
Melancholijna nastrojowość budowana jest także poprzez nawiązanie do dzieł malarstwa. Poeta przywołuje senny obraz Wyspa umartych Arnolda Böcklina. Park miejski ukazany jest jako tajemnicze miejsce - właśnie jako wyspa - pełne grozy, otoczone mrokiem, do którego żywi także mają dostęp. Jednak bohater zdaje się przeczyć emocjom związanym z przemijaniem, gdyż jest świadomy swojej młodości:

$$
\begin{aligned}
& \text { Iść pańską - sam - zadumanemi nocami } \\
& \text { koło zamkniętych bram } \\
& \text { koło parku- wyspy umarłych Boecklina - } \\
& \text { i słuchać rytmu swych kroków } \\
& \text { tak jeszcze młodych }{ }^{77} \text {. }
\end{aligned}
$$

Dalej ta sama mroczna nastrojowość kreowana jest poprzez postać kobiety, być może widziadła - wpływu księżycowego blasku na wyobraźnię. Bohater wiersza nie ufa zmysłowi wzroku. Cały czas także zdaje się ulegać mrocznemu wpływowi parku - wyspy umarłych:

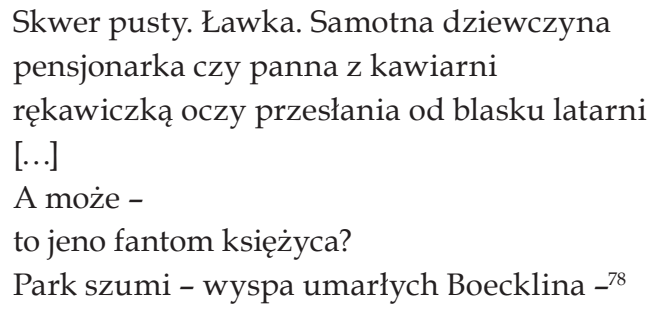

Znów tak jak w wierszu Gotębiarz pojawia się zabieg geometryzacji przestrzeni. Tym razem owa geometryczność nie dotyczy jednak samych budowli miejskich, ale ich cieni. Są to odbicia fabryk: przędzalni i tkalni. Również bramom placów został nadany regularny, symetryczny kształt łuku:

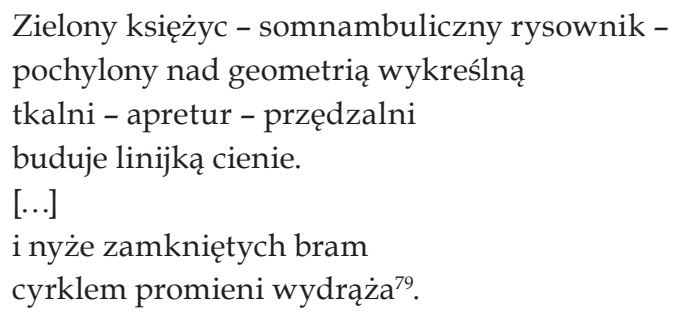


Łódź niezaprzeczalnie wiąże się z pracą fabryk. Również tego motywu nie pominął Wandurski w swoim poemacie. Był mu on zresztą bliski jako człowiekowi o poglądach lewicowych, a nawet komunistycznych. Fabryki i ich kominy ukazał poeta jako obiekty majestatyczne, uświęcone pracą. Porównał je do świątyń - kościołów lub meczetów, pracowników zaś - do wiernych:

\section{Minarety}

zamorusane kominy

budzą się zwolna i kadzą dymu obłoki.

Meczety

czerwone bloki

[...]

Organy maszyn, ukryte w gorącej parze

grają hymn pracy.

Migają koła ruchomych ołtarzy ${ }^{80}$.

Poeta zwraca uwagę na wielokulturowość tej „wiernej” masy dążącej do fabryk. Znamienne jest, że przypisuje on stereotypowe cechy tylko dwóm narodowościom, natomiast nie wyodrębnia cech Polaków:

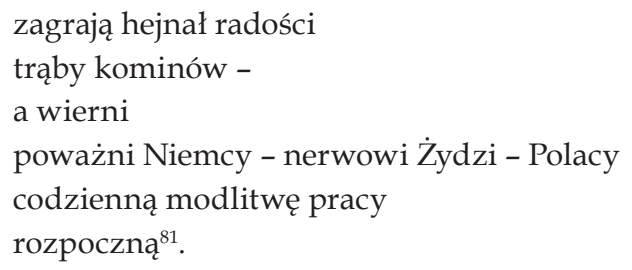

Kolejną postacią, której warto przyjrzeć się bliżej, jest Konstanty Dobrzyński ${ }^{82}$. Został on pośród omawianych w niniejszej pracy poetów najbar-

\footnotetext{
$80 \quad$ Tamże, s. 17.

81 Tamże, s. 18.
}

82 Urodził się i wychował w jednej z najbiedniejszych dzielnic Łodzi - na Chojnach. Przyszedł na świat 20 grudnia 1908 roku w ubogiej robotniczej rodzinie. Jego ojciec z zawodu był studniarzem; zginął młodo podczas I wojny światowej. Matka poety, aby uniknąć biedy, wyjechała z dziećmi do rodziny na Kujawy, gdzie mały Konstanty zajmował się pasaniem krów. Po kilku latach powrócili do Łodzi. Feliks Bąbol tak wspomina los matki Dobrzyńskiego, która sama musiała utrzymać rodzinę po stracie męża: „Była posługaczką w Domu Starców przy Narutowicza i za 60 złotych musiała wyżywić siebie i dwoje dzieci. Z czasem przychodziło jej to łatwej, bo nawiązawszy dobre stosunki z kucharką przynosiła raz po raz nadliczbowy kotlet do domu". F. Bąbol, Łódź, która odeszła..., Łódź 1973, s. 75.

Co prawda młody Dobrzyński przed śmiercią ojca zdążył poznać fach studniarza, ale w dzielnicy, w której przyszło mu żyć, mieszkali ludzie niezamożni, więc i nie każdego było stać na wybudowanie studni. Pracy miał mało. Dalej wspomina Bąbol w swojej książce: „w izbie wynajmowanej przez Dobrzyńskich przy Bankowej można było zastać Kostka prawie przez okrągły rok. Gdy siostra chodziła do szkoły, Kostek całymi dniami przesiadywał w tej izbie, uzupełniając swe skromne wykształcenie zdobyte w powszechniaku. Miesiącami wczytywał się w historię literatury, botanikę i zoologię, całe godziny spędzał nad Marksem. Chwytał każdą książkę i wysysał z niej, co tylko mógł. W tym mieszkaniu przy Bankowej często psuły 
dziej doświadczony przez życie. Dwukrotnie przerywał naukę (raz po śmierci ojca, drugi podczas choroby matki, kiedy to musiał podjąć pracę) - niestety braki w wykształceniu widać w jego twórczości. Również niekorzystny, bo polityczny i ideologiczny wpływ na jego wiersze wywarło sympatyzujące z endecją czasopismo "Orędownik", z którym łodzianin współpracował. Gicgier w swojej książce pt. Opowieści o dawnych poetach Łodzi cytuje publicystów nie szczędzących krytyki Dobrzyńskiemu. Byli to Władysław Sebyła i Karol Zawodziński:

Można by w nim też odkryć zadatki na poetę, lecz raczej zasługuje na nazwę wierszopisa. Wprowadza czasem dobre motywy alegoryczne (wiersz Jesień), lecz możliwości poetyckie toną w powodzi banalnej, dziennikarskiej frazeologii, w wytartych obrazach i przenośniach. [...] Obrazowanie tego, wychwalanego przez pewne sfery polityczne autora jest często wręcz grafomańskie [opuszczenie moje - S. K.] ${ }^{83}$.

Wprawdzie niektóre utwory istotnie mogłyby uzasadniać określenie "Żagwi na wichrach" jako „poezji pięści”, ale nawet one mówią więcej o histerii i o próbach literackiego ujęcia krzykliwych haseł grupy, dążącej do narzucenia swej brutalnej władzy współobywatelom, niż o istotnie męskiej sile i powadze ${ }^{84}$.

się kotlety z Domu Starców, bo Kostek ich nie jadł, gdyż doskonale opanował uczucie głodu, a cudzymi kotletami gardził". Tamże, s. 76.

Podjął się pracy w fabryce Scheiblera jako robotnik budowlany. Pozostał tam przez dwa lata, a naukę kontynuował $\mathrm{w}$ wieczorowym gimnazjum, gdzie zdał maturę. Tworzył $\mathrm{w}$ latach trzydziestych, kiedy to w Łodzi coraz bardziej widoczne były bieda i bezrobocie. Jego wiersze publikowano na łamach "Głosu Porannego" (dziennika o orientacji socjaldemokratycznej, wydawanego w Łodzi w latach 1929-1939; pierwszym redaktorem pisma był Jan Urban, ojciec znanego publicysty, satyryka i polityka Jerzego Urbana). Jeszcze przed opublikowaniem swojego debiutanckiego tomu (Czarna poezja, 1936) podjął pracę w łódzkim wydaniu poznańskiego dziennika społeczno-politycznego "Orędownik" (1871-1939). Tuż po debiucie otrzymał posadę w centrali tego pisma, dlatego przeniósł się do Poznania. Jego wiersze często służyły redakcji w politycznej walce. Niektóre utwory poety zostały napisane na zamówienie. Feliks Bąbol w swojej książce umieścił związany z tym faktem cytat Dobrzyńskiego: „Wstydzę się tego, co mi drukują w gazecie - mawiał do przyjaciół i kolegów ale... co mam robić?" (F. Bąbol, dz. cyt., s. 78). Nie wiadomo jednak, czy słowa te wypowiedział sam Dobrzyński, czy być może ktoś z jego przyjaciół wstydził się za niego i włożył je w usta pisarza.

Za swój drugi tom poetycki (Żagwie na wichrach, 1938) wiosną 1939 roku Dobrzyński otrzymał nagrodę tygodnika „Prosto z mostu”, prawdopodobnie ze względów politycznych lub ideowych, gdyż krytycy surowo oceniali jego twórczość.

Tematyka Żagwi na wichrach jest dość zróżnicowana. Tom składa się z pięciu cyklów. Znajdziemy tam wiersze sielankowe, jak np. Wiosna, Lipiec, Matka, jest rozdział w całości poświęcony Łodzi, są wiersze o tematyce społecznej, religijnej oraz politycznej, m.in. Na nowe tory, Młodzi, panegiryk na cześć Romana Dmowskiego czy wiersz Rocznica upamiętniający powstanie listopadowe.

Zginął 3 września 1939 roku w Janowie Lubelskim, walcząc z Niemcami. Zob. T. Gicgier, dz. cyt., s. 119.

83 W. Sebyła, Liryka, „Rocznik Literacki za rok 1935”, Warszawa 1936, s. 32, cyt. za: T. Gicgier, dz. cyt., s. 113.

84 K. Zawodziński, Liryka i epika wierszem, [w:] „Rocznik Literacki za rok 1938”, Warszawa 1939, s. 29, cyt. za: T. Gicgier, dz. cyt., s. 113-114. 
Fascynacja utworami polskich klasyków poezji była charakterystyczna zarówno dla Brauna, jak i Dobrzyńskiego. Wielkim marzeniem poety z Chojen było spotkanie "legendy” literatury - Leopolda Staffa. Łodzianin dopiął swego. Odwiedził „mistrza” w Warszawie ${ }^{85}$.

Pod względem wersyfikacji większość wierszy Dobrzyńskiego zbudowana jest na sposób klasycystyczny, podobnie jak wiersze skamandrytów. Razi jednak czytelnika przy lekturze niektórych utworów poety zamiłowanie do utartych i mało oryginalnych zabiegów literackich, jak np. personifikowania pór roku czy miesięcy:

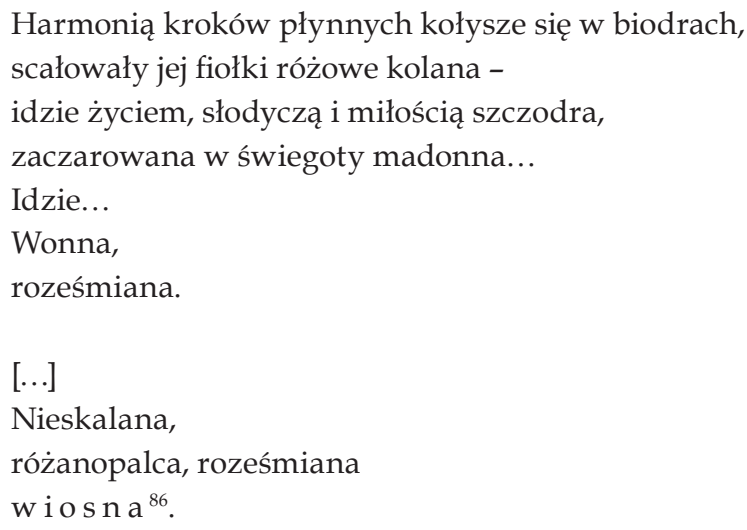

Najbardziej uderza czytelnika jednak to, że tom w całości został dedykowany polskiemu robotnikowi. Czytamy na jednej z początkowych stron Czarnej poezji: „Robotnikowi polskiemu, Jego nędzy trudom i znojom, Jego twardej i nieustającej walce o lepsze jutro, Jego roli w przyszłej, Odrodzonej Wielkiej Polsce poświęcam" ${ }^{\prime 87}$.

Dziwny to pomysł łączyć wiersze proletariackie, tj. Strajk, wiersze polityczne, jak np. Dmowski, z wierszami dla dzieci. Na uwage zasługuje też sposób obrazowania. Metafory Dobrzyńskiego zdają się łamać konwencje tworzenia obrazów literackich. Tak jest np. z niektórymi wersami w wierszu pt. Zadymiony gród:

$\mathrm{O}$, miasto spowinięte w gęste dymu chmury,

z wiecznie rozkopywaną i targaną jezdnią,

gdzie na peryferiach obszarpane mury

chcą walczyć swą brzydotą z Twoich kałuż bezdnią!

[...]

A jednak kocham Ciebie, zadymiony grodzie,

Całuję wzrokiem dziurawe Twe chodniki,

85 F. Bąbol, dz. cyt., s. 75.

86 K. Dobrzyński, Wiosna, [w:] tegoż, Czarna poezja, Poznań 1936, s. 16-17.

87 Tenże, [dedykacja do:] Czarna poezja, s. 7. 
Gdzie moi najbliżsi w zwartym korowodzie

Szli, by zdążyć na gwizdek do brudnej fabryki ${ }^{88}$.

Łódź w liryku tym jest zarówno brzydka, jak i pociągająca ${ }^{89}$. Wydaje się, iż poeta usiłuje stworzyć wiersz w myśl Tuwimowskiej frazy - „Więc kocham twą «urodę złą»,/Jak matkę niedobrą - dziecię"90 - ale czytelnik może mieć wrażenie, że Dobrzyński przesadził ze środkami artystycznymi, w tym przypadku z hiperbolą: „kałuż bezdnią”. Doprawdy trudno wyobrazić sobie bezdnię kałuży - albo kałużę bezdenną. Można mieć też wątpliwość, czy estetycznie uzasadniona jest fraza: „Całuję wzrokiem dziurawe Twe chodniki”. Czy też poeta dał się uwieść zbyt wybujałej wyobraźni?

Melancholia także pojawia się w wierszach Konstantego Dobrzyńskiego, ale już w zdecydowanie mniejszym natężeniu. Szczególnie dostrzegalna jest w liryku pt. Łódź w nocy z tomu Czarna poezja. Poeta prowadzi nas przez ulice sennego miasta. Wymienia takie detale architektury i przestrzeni jak kominy, kamienice, jezdnie, rynsztoki, latarnie czy tramwaje. Dla poety miasto żyje, toteż pod jego piórem ulega antropomorfizacji lub animizacji:

niezliczone kominy, co w dzień dymem zioną, sterczą senne i ciche, czarnymi paszczami

pijąc metal księżyca [...]

Śpią, okrywszy się cieniem kamieniczne bloki i prostują swe członki jezdnie spracowane, oparłszy nagie stopy o brudne rynsztoki świecą blade latarnie, nad czymś zadumane ${ }^{91}$.

Warto przyjrzeć się bliżej temu zabiegowi poetyckiemu. Takie sformułowania jak „dymem zioną” czy „czarnymi paszczami piją” wskazują raczej na cechy baśniowych stworów niż zwykłych zwierząt. Melancholia zawarta jest natomiast w wyrażeniach "latarnie, nad czymś zadumane”, „wymarłe ulice" albo „wiatr [...], co dziwny nokturn nuci [...] i różnymi głosami nocną ciszę kłóci" ${ }^{\prime \prime 2}$.

W wierszach Dobrzyńskiego ważną rolę odgrywa przyroda. W tomie z 1936 roku znajdziemy co najmniej kilkanaście utworów, w których pojawiają się kwiaty, łąki czy drzewa. Jako człowiek wychowany na przedmieściach Łodzi, na Chojnach, przyzwyczajony do życia pośród natury, poeta próbuje

88 Tenże, Zadymiony gród, [w:] tegoż, Czarna poezja, s. 51.

89 Tomasz Cieślak wykazał, iż taka paradoksalna fascynacja brzydotą w postrzeganiu Łodzi jest charakterystyczna dla większości łódzkich poetów, zarówno dla Tuwima, Piechala, jak i Sztaudyngera. T. Cieślak, dz. cyt., s. 493.

90 J. Tuwim, Łódź, [w:] Z. Skibiński, B. Stelmaszczyk-Świontek, Kwiaty tódzkie. Antologia poezji o Łodzi, Łódź 1982, s. 129.

91 K. Dobrzyński, Łódź w nocy, [w:] tegoż, Czarna poezja, s. 53.

92 Tamże. 
szukać w przemysłowym krajobrazie choćby najdrobniejszych jej oznak. Tak dzieje się $\mathrm{w}$ wierszu pt. Wiosna w Łodzi, w którym miasto jest prezentowane jako ciemne, ponure i brudne, a nawet więcej - postrzegane w sposób naturalistyczny:

Poprzez ciemń gęstych dymów błysnął promień złoty.

Zślizgnął się po kominach i po murów bloku

I do ciemnych suteryn puścił się w zaloty;

Poigrał po śmietnikach, przejrzał się w rynsztoku.

[...]

Przestrzelił chmury pyłu i w twarz robotnika

Spotniałą, zakurzoną, złotym blaskiem trysnął! ${ }^{13}$

I w tym nieprzyjemnym, sztucznym dla człowieka środowisku pojawiają się elementy przyrody:

Ze skarlałych krzewów

Dolatywał chór ptasich szczebiotów i śpiewów.

I biła hen w niebiosa cudna pieśń radosna.

Robotnik szepnął z cicha: - Prawda, wszak to w i o s n a ! ${ }^{94}$.

Nieszczęśliwy jest robotnik, który zamknięty w czterech ścianach fabryki, pracujący w pocie czoła, nie dostrzega zmian zachodzących w naturze - zdaje się brzmieć puenta wiersza.

Inaczej dzieje się w liryku pt. Na Chojnach. Poeta ukazuje swoją rodzinną dzielnicę jako krainę niezgłębionej radości, przestrzeń niezwykle sielankową. Są to dwa bliskie, a jednocześnie w pewien sposób zupełnie odległe światy: przemysłowa Łódź pełna murów i pobliskie Chojny otoczone ogrodami, drzewami i kwiatami:

Na Chojnach, z dala od gwarnego miasta,

gdzie się już kończą tramwajowe szyny,

nagle pod stopą inny świat wyrasta:

ogrody, drzewa, pęki bzów, jaśminy... ${ }^{95}$

Dobrzyński poświęca również cały wiersz parkowi Poniatowskiego. Wyraża zachwyt nad jego florą, wymienia całą paletę dostrzegalnych w nim barw:

Kwieciste plamy. Żwir. Obłok zieleni.

Słońce - kadź wielka z roztopionem złotem.

93 Tenże, Wiosna w Łodzi, s. 52.

94 Tamże.

95 Tenże, Na Chojnach, [w:] tegoż, Czarna poezja, s. 56. 
Rozbłękitnione ziewają przestrzenie.

Drżą listki krzewów jarzącym nalotem.

[...]

Nad stawu gładką, mieniącą się misą,

schylony łowi swe oblicze na dnie,

zda się do głębin za chwilę zapadnie

skroplony złotem modry kwiat irysu.

[...]

A gdy się zorzą niebo zaróżowi,

gorętszym szeptem bzu krzew rozwonieje -

spłynie z przestworzy srebrny krąg na nowiu,

by się przechadzać parkową aleją... ${ }^{96}$

Spośród czworga prezentowanych w niniejszej pracy literatów żaden nie przejawia takiego emocjonalnego stosunku do Łodzi jak Konstanty Dobrzyński. Zażyłość z rodzinną miejscowością wyrażona została bodaj najsilniej w liryku pt. Dwa miasta. Poeta, posługując się zabiegiem personifikacji, ukazuje kontrast pomiędzy Poznaniem i Łodzią. Nadwarciańskie miasto jest czyste, zadbane, pełne zabytkowych budowli:

Jesteś bardzo „nobliwy” dostojny Poznaniu.

Siedzisz czysto wymyty nad brzegami Warty, dostojny, okazały, że poznać cię warto.

Jesteś, jak pełna taktu, ugrzeczniona pani.

$[\ldots]$

I gdy mi podawałeś mile skinąć racząc

na błyszczących asfaltów polewanej tacy -

pyszne ciasta - twe wille, operę, pałace,

nie wiedziałem naprawdę od którego zacząć ${ }^{97}$.

Ale podmiot liryczny w tej pełnej wdzięku przestrzeni nie czuje się dobrze. Kobieta-robotnica uosabia Łódź, jego matkę, ukazaną po części w sposób naturalistyczny, spracowaną, brudną i chorą, dlatego też odczuwa on kompleks niższości. Według Tomasza Cieślaka personifikację Łodzi jako matki szczególnie chętnie stosowali poeci zaangażowani politycznie czy społecznie. Zabieg ten dostrzeżemy także w twórczości Jana Sztaudyngera (fraszka Do Łodzi) czy Mariana Piechala (wiersz o identycznym tytule: Do Łodzi $)^{98}$. U Dobrzyńskiego znów pojawiają się specyficzne dla przemysłowego miasta elementy architektury - dym fabryk, bruk i rynsztoki.

\footnotetext{
96 Tenże, Park Poniatowskiego, [w:] tegoż, Czarna poezja, s. 55.

97 Tenże, Dwa miasta, [w:] tegoż, Żagwie na wichrach, s. 11.

98 T. Cieślak, dz. cyt., s. 495.
} 
A ona już czekała na mnie przy rogatkach, zaharowana taka, ot... od balii prosto.

Tam przy dworcu kaliskim usiadła pod mostem, W dal oczy wypatrując - moja dobra matka.

Widziałem już z daleka jej głowę znużoną i włosy rozkudłane - bure dymy fabryk i oczy jej wypełzłe, zmęczeniem czerwone, które kiedyś na pewno kwitnęły jak chabry.

Stała trochę niepewna, cicha, zalękniona, w rynsztokami brudnymi schlapanej spódnicy i ręce z pęcherzami bruków - swe ulice wyciągnęła czekając, gdy biegłem w jej stronę ${ }^{99}$.

Po przyjrzeniu się twórczości wybranych łódzkich poetów możemy zauważyć, że każdy z nich przejawiał inny stosunek do pisarstwa. Świadczą o tym już same tematy podejmowane przez tychże literatów. Przedborska zaangażowana w służbę społeczeństwu, Dobrzyński - aktywny poeta polityczny. Nieco bardziej nowocześni wydają się Braun, u którego nietrudno dostrzec popularne motywy pracy i rzemiosł związane z rozwojem gospodarczym kraju, oraz Wandurski, przede wszystkim ze względu na sposób potraktowania przez niego przestrzeni miejskiej. Jak udowadnia Elżbieta Rybicka w pracy poświęconej przestrzeni miejskiej w literaturze, takie widzenie miasta nie jest przypadkowe.

Rybicka, znawczyni geopoetyki, wskazuje na przełom, jaki dokonał się $\mathrm{w}$ postrzeganiu aglomeracji miejskich $\mathrm{w}$ literaturze na przełomie XIX i XX wieku. Objął on m.in. zmianę perspektywy - ujęcia panoramiczne zastąpił widok z punktu widzenia przechodnia:

Kwestia wyboru perspektywy - tak przestrzennej, jak narracyjnej - jest sprawą zasadniczą dla sposobu prezentacji miasta. Symptomem nowoczesnego przedstawiania przestrzeni miejskiej, jak przyjęto uważać, jest swoista „rewolucja percepcyjna”: przejście od zewnętrznego punktu widzenia (panoramicznego, z lotu ptaka lub, jak w dawnych wedutach, spoza granic miasta) do wewnętrznego (percepcji doświadczanej przez przechodnia), od osi wertykalnej do horyzontalnej. Perspektywa panoramiczna sytuuje się ponad lub poza miastem, zakłada nieruchomy punkt widzenia, ogląd całości i dystans przestrzenny, perspektywę przechodnia natomiast warunkuje ruch i zmienność punktów widzenia, zniesienie bądź skrócenie dystansu ${ }^{100}$.

99 K. Dobrzyński, Dwa miasta, s. 11.

100 E. Rybicka, Modernizowanie miasta: zarys problematyki urbanistycznej w nowoczesnej literaturze polskiej, Kraków 2003, s. 109. 
Tę różnicę możemy dostrzec również w cytowanych wcześniej utworach łódzkich poetów. Dobrzyński w Zadymionym grodzie i Braun w Łodzi fabrycznej opisują jeszcze przestrzeń miejską z perspektywy panoramicznej. W ich wierszach mamy do czynienia z całościowym, szerokim obrazem miasta.

Natomiast Witold Wandurski w poemacie Od pótnocy do świtu przechadza się ulicami Łodzi, co świadczy o jego modernistycznym podejściu do literatury:

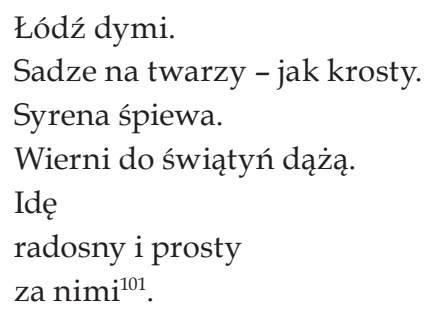

Rybicka w swojej książce, w części poświęconej estetyzacji przestrzeni miejskiej, wskazuje również na opozycję miasto - wieś, która wytworzyła się w czasach romantyzmu i obowiązywała aż do dwudziestolecia międzywojennego. W wolnej Polsce na miejską egzystencję można było spojrzeć z innej perspektywy - obywatela niepodległego państwa. Niemal przez cały XIX wiek cywilizacja wielkomiejska ulegała napiętnowaniu, kojarzyła się najczęściej z degradacją ludzkiej moralności i grzechem: „Miasto w tradycji polskiej mogło być Babilonem, Sodomą, Molochem, dżunglą, pustynią, w każdym razie przestrzenią destruującą więzi społeczne i pozbawioną wartości estetycznych"102.

W oczach awangardzistów, którzy byli prekursorami nowego spojrzenia, objawiało się ono jako dzieło sztuki. Fascynowało ich to, co działo się na ulicach wielkich miast: tłumy ludzi, tętniące życie, symbole nowoczesności i techniki - auta i elektryczność. Trzeba było również inaczej spojrzeć na miejski pejzaż, na jego architekturę i odkryć na nowo ich piękno.

\begin{abstract}
Przedstawianie miasta jako dzieła sztuki w przypadku poetyki konstruktywistycznej kładzie nacisk na uporządkowanie, planowość układu kompozycyjnego. Decydujące znaczenie ma fakt, że miasto jest przeciwieństwem natury, stanowi planowaną organizację przestrzeni, a ten antynaturalizm manifestuje się zwłaszcza w geometryzacji pejzażu miejskiego, miasta konstruktywistów zabudowane są bowiem figurami geometrycznymi ${ }^{103}$.
\end{abstract}

Fragment tekstu Rybickiej wyjaśnia też, skąd u Wandurskiego zabieg geometryzacji miejskiej przestrzeni, którym posługiwali się również Tadeusz Peiper, Jalu Kurek czy Julian Przyboś.

\footnotetext{
101 W. Wandurski, Od pótnocy do świtu, s. 18.

102 E. Rybicka, dz. cyt., s. 239.

103 Tamże, s. 245.
} 


\section{Zakończenie}

W międzywojniu w Łodzi nie wykształciła się grupa poetów o wspólnym programie poetyckim lub charakterystycznym tylko dla niej warsztacie. O łódzkiej szkole poetyckiej dwudziestolecia międzywojennego raczej mówić nie możemy. Inaczej sytuacja miała się po wojnie. Ewa Głębicka w swojej książce pt. Grupy literackie w Polsce 1945-1989 wymienia aż dwanaście grup literackich funkcjonujących w Łodzi w okresie od zakończenia II wojny światowej do upadku komunizmu ${ }^{104}$. Zaprezentowana czwórka poetów to cztery indywidualności. Wandurski - awangardzista, Dobrzyński i Braun zaangażowani politycznie, miłośnicy twórczości skamandrytów i klasyków (ten pierwszy ideowo bliski endecji, drugi zaś lewicy), Przedborska - poetka tkwiąca głęboko w dziewiętnastowiecznym naturalizmie.

Liryki łódzkiej nie można uznać za tak rozwiniętą jak lirykę innych wielkich aglomeracji: Warszawy czy Krakowa, bo i historia Łodzi nie jest tak bogata. W porównaniu z najstarszymi ośrodkami kulturowymi fabryczne miasto rozwija się późno. Ale "gród kominów” musi odznaczać się czymś niezwykłym, skoro pisali o nim tacy wybitni pisarze jak Julian Tuwim, Władysław Broniewski, Julian Przyboś, Jarosław Iwaszkiewicz czy Jarosław Marek Rymkiewicz.

Łódzkie środowisko literackie ciągle ewoluuje. Z każdą dekadą dołącza do niego nowa grupa młodych poetów. Ogłasza się coraz więcej konkursów dla twórców liryki. Najbardziej znane z nich to: konkurs poetycki pod patronatem Stowarzyszenia Literackiego im. Krzysztofa Kamila Baczyńskiego, Ogólnopolski Konkurs Poetycki dla Młodych Twórców im. Zbigniewa Dominiaka - „Moje świata widzenie" (organizowany przez Dom Literatury w Łodzi oraz Stowarzyszenie Pisarzy Polskich Oddział w Łodzi) czy Ogólnopolski Konkurs Poetycki im. Jacka Bierezina. Organizowane są również konkursy prozatorskie.

Kontynuowana jest także tradycja wydawania czasopism literackich. W dwudziestoleciu międzywojennym były to - co prawda krótko działające - „Tańczący Ogień" czy „Meteor”, w których publikowali, a i często debiutowali, najwybitniejsi literaci jak Tuwim czy Słonimski. Dziś ukazują się „Tygiel Kultury” oraz „Arterie”. Warunki do uprawiania literatury są coraz korzystniejsze, a i sama Łódź pojawia się w twórczości coraz młodszych łódzkich poetów. Piszą o niej m.in. Piotr Macierzyński, Przemysław Owczarek, Kacper Płusa czy Szymon Domagała-Jakuć. Prawdopodobnie już niedługo doczekamy się wielu opracowań nowej łódzkiej poezji.

przypowieść o łodzi

jak zmienić bieg wydarzeń w mieście, które nie posiada rzeki, nie niesie głosu ryb, choć leży u źródeł? jest cieczą, która przystosowuje się do kształtu naczynia, a ruch w nim to tylko załamania fal.

104 E. Głębicka, Grupy literackie w Polsce 1945-1989. Leksykon, Warszawa 2000, s. 694. 
gdy jesienią owijam się w płaszcz z lęku przed deszczem, przed nabraniem wody w usta,

na odwrocie jak na etykiecie powinienem podać skład, swoją krótką charakterystykę,

to, co wyniosłem, poddając się pływom: ulice, które przypominają czaszkę czare goryczy, bezwolne opadanie na dno, odruch chwytania za brzytwę $e^{105}$

\section{B I B L I O GRA A I A}

Bąbol F., Łódź, która odeszła..., Łódź 1973.

Braun M., Wiersz o Łodzi, [w:] Łódź od A do Z. Informator uniwersalny, Łódź 1958.

Braun M., Wybór poezji, Warszawa 1979.

Cieślak T., Kilka uwag o przedstawieniach przestrzeni łódzkiej w liryce, [w:] Studia i prowincje kultury. Księga jubileuszowa ofiarowana profesor Alinie Kowalczykowej, pod red. J. Brzozowskiego, M. Skrzypczyka i M. Stanisza, Warszawa 2012.

Dobrzyński K., Czarna poezja, Poznań 1936.

Dobrzyński K., Żagwie na wichrach, Poznań 1938.

Gicgier T., Opowieści o dawnych poetach Łodzi, Łódź 1995.

Glisczyński A., Z mroku i dymu. Poezje, Warszawa 1901.

Głębicka E., Grupy literackie w Polsce 1945-1989. Leksykon, Warszawa 2000, s. 694.

Hemer A., Twarz lodzermenscha, czyli wizerunek człowieka łódzkiego w "Ziemi obiecanej" Wtadystawa Stanistawa Reymonta, "Czytanie Literatury” 2013, nr 2.

Karwacka H., Artur Glisczyński, pieśniarz fabrycznej Łodzi, Łódź 1975.

Kempa A., Odkryta tajemnica. Kim była Maria Przedborska, „Kronika Miasta Łodzi” 2008, nr 3.

Kempa A., Szukalak M., Żydzi dawnej Łodzi. Słownik biograficzny Żydów łódzkich i z Łodzią związanych, t. 4, Łódź 2004.

Kotowska-Kachal M., Wspótcześni polscy pisarze i badacze literatury, t. 9, W-Z, Warszawa 2004.

Kwiatkowski J., Dwudziestolecie międzywojenne, Warszawa 2012.

Płusa K., Ze skraju i ze światła, Łódź 2012.

Przedborska M., Niedziela letnia, „Ilustrowana Rewia Tygodniowa”1935, nr 33.

Przedborska M., [Osiem] 8 godzin, "Głos Poranny” 1934, nr 354, dod. „Specjalny dodatek świąteczny".

Przedborska M., Robotnicy łódzkiej, „Głos Poranny” 1934, nr 354, dod. „Specjalny dodatek świąteczny".

Przedborska M., Suchoty, „Ilustrowana Rewia Tygodniowa”1934, nr 22.

Rybicka E., Modernizowanie miasta: zarys problematyki urbanistycznej w nowoczesnej literaturze polskiej, Kraków 2003.

Skibiński Z., Stelmaszczyk-Świontek B., Kwiaty łódzkie. Antologia poezji o Łodzi, Łódź 1982. Stownik wyrazów obcych PWN, pod. red. Hipolita Szkiłądzia, Warszawa 1971.

Stolarzewicz L., Literatura Łodzi w ciagu jej istnienia. Szkic literacki i antologia, Łódź 1935.

105 K. Płusa, Przypowieść o Łodzi, [w:] tegoż, Ze skraju i ze światła, Łódź 2012, s. 26. 
Tyszkiewicz B., Braun Mieczysław, [w:] Wspótcześni polscy pisarze i badacze literatury. Stownik biobibliograficzny, pod. red. J. Czachowskiej i A. Szałagan, t. 1, A-B, Warszawa 1994. Wandurski W., Sadze i złoto, Łódź 1926.

\section{STRESZCZENIE}

Artykuł jest przeglądem osiągnięć łódzkiego polskojęzycznego środowiska literackiego w okresie międzywojennym. Punkt odniesienia stanowi twórczość poety Artura Glisczyńskiego. Bliższej analizie poddana została liryka czworga tworzących w dwudziestoleciu poetów: Marii Przedborskiej, Mieczysława Brauna, Witolda Wandurskiego oraz Konstantego Dobrzyńskiego. Autor tekstu przygląda się zróżnicowanej poetyce łódzkich artystów oraz wpływowi sztuki dwudziestolecia międzywojennego na ich twórczość. Głównym tematem refleksji jest jednak miasto, jego przestrzeń, mieszkańcy i motywy pokrewne.

\section{Słowa kluczowe}

liryka, XIX wiek, XX wiek, dwudziestolecie międzywojenne, Łódź

\section{S U M M A RY}

\section{Lodz poets of the interwar period and their city}

The paper is an overview of some achievements of Lodz Polish-speaking literary circles in the interwar period. The point of reference is the poetic output of Artur Glisczyński. Closer analysis includes lyrical poetry of four poets of the interwar period: Maria Przedborska, Mieczysław Braun, Witold Wandurski and Konstanty Dobrzyński. The author of the text analyzes the diversified poetics of Lodz artists and the impact of interwar art on their literary output. The main topic of reflection is, however, the city, its space, inhabitants and related motifs.

\section{Keywords}

lyrical poetry, 19th century, 20th century, interwar period, Lodz 